\title{
Production and morphological components of sunflower on soil fertilized with cassava wastewater
}

\author{
Mara Suyane Marques Dantas ${ }^{1}$, Mario Monteiro Rolim ${ }^{1 *}$, Anamaria de Sousa Duarte ${ }^{1}$, \\ Luiz Evandro de Lima², Manassés Mesquita da Silva ${ }^{1}$
}

$10.1590 / 0034-737 X 201764010011$

\begin{abstract}
Agroindustrial residues, such as cassava wastewater, have been used as soil fertilizers, reducing environmental pollution and recovering nutrients. The objective of this work was to evaluate production and morphological components and oil yield of sunflower (Helianthus annuиs), hybrid Helio-250, fertilized with cassava wastewater. The experiment was conducted at the Experimental Station of the Instituto Agronômico of Pernambuco, Vitória de Santo Antão, State of Pernambuco, Brazil. A randomized block experimental design was used, with six cassava wastewater rates $(0,8.5,17.0$, 34.0, 68.0 and $136 \mathrm{~m}^{3} \mathrm{ha}^{-1}$ ) and four replications. The variables evaluated were shoot fresh and dry weight, capitulum fresh and dry weight, capitulum diameter, seed yield, oil yield and seed oil content. The use of cassava wastewater as soil fertilizer improved the production and morphological variables evaluated, except the seed oil content, which decreased with application of cassava wastewater rates above $25 \mathrm{~m}^{3} \mathrm{ha}^{-1}$.
\end{abstract}

Key words: Helianthus annuus; Manihot esculenta, agroindustrial residues; seed oil content.

\section{RESUMO}

\section{Uso de manipueira como fonte de nutrientes nos componentes morfológicos e de produção do girassol}

O uso dos resíduos advindos de atividades agroindustriais, como a manipueira, vem sendo aplicado como forma de diminuir a poluição ambiental e aproveitamento de nutrientes. Assim, objetivou-se com o estudo, avaliar os componentes de produção e o rendimento de óleo do girassol (Helianthus annuus), híbrido Helio 250, fertilizado com manipueira. Conduziu-se experimento na Estação Experimental do Instituto Agronômico de Pernambuco, localizada em Vitória de Santo Antão - PE. O delineamento experimental adotado foi em blocos casualizados, constituídos de seis tratamentos (doses de manipueira: 0; 8,5; 17,0; 34,0; 68,0 e $136 \mathrm{~m}^{3}$ ha $^{-1}$ ) e quatro repetições. Foram determinadas as variáveis rendimento de matéria fresca e seca da parte aérea das plantas; rendimento de matéria fresca e seca do capítulo; diâmetro de capítulo, rendimento de aquênios, rendimento e teor de óleo do girassol. O uso da manipueira como fonte de fertilizante proporcionou aumento das variáveis morfológicas e de produção avaliadas, exceto o teor de óleo das sementes, que diminuiu para doses de manipueira acima de $25 \mathrm{~m}^{3} \mathrm{ha}^{-1}$.

Palavras-chave: Helianthus anпииs; resíduos agroindústrias; teor de óleo.

\footnotetext{
Submitted on July 10 $10^{\text {th }}, 2014$ and accepted on November $11^{\text {th }}, 2016$.

${ }^{1}$ Universidade Federal Rural de Pernambuco, Departmento de Engenharia Agrícola, Recife, Pernambuco, Brazil. marasuyane@hotmail.com; mario.rolim@ufrpe.br; asousaduarte@gmail.com; manasses.mesquita@ufrpe.br

${ }^{2}$ Instituto Agronômico de Pernambuco, Recife, Pernambuco, Brazil. luiz.evandro@ipa.br

*Corresponding author: mario.rolim@ufrpe.br
} 


\section{INTRODUCTION}

Sunflower (Helianthus annuus L.) stands out as one of the four main oil-producing crops in the world, with increasing importance to international agriculture. Sunflower crops are mainly related to seed oil production for human consumption and biofuel production. The Brazilian sunflower production is not very significant, with only $109,000 \mathrm{Mg} \mathrm{yr}^{-1}$ (average grain yield of $1581.3 \mathrm{~kg} \mathrm{ha}^{-1}$ and average oil yield of $563.80 \mathrm{~kg} \mathrm{ha}^{-1}$ ), while Ukraine is the the world's largest producer with approximately 11 million $\mathrm{Mg} \mathrm{yr}^{-1}$ and average seed yield of $2170 \mathrm{~kg} \mathrm{ha}^{-1}$ (FAO, 2015).

The Brazilian agroindustrial sector generate approximately 330 million $\mathrm{Mg}$ of waste per year, which can be reused for several purposes, including energy production and soil fertilization (Moraes et al., 2012; Virmond, 2011). These residues have high concentration of nutrients and organic matter, thus, they can improve the soil fertility and, consequently, increase the yield of agricultural crops (Grigatti et al. 2011).

Among the many agroindustrial residues, there are those from the cassava processing for table flour and starch production, which generates residues containing solids, consisting of the woody parts of roots, fibrous fraction retained in sieves and the cassava biomass, and liquids, consisting of the root-wash water and cassava pressing water, which is commonly known as cassava wastewater (Magalhães et al., 2014).

The cassava wastewater has high content of mineral nutrients and organic compounds and the cyanogenic glycoside linamarin, a source of hydrocyanic acid, which can cause serious environmental problems when improperly disposed, such as reduction of dissolved oxygen and eutrophication of water bodies, death of aquatic fauna and terrestrial animals that consume water with excess hydrocyanic gas, and imbalance of soil nutrients (Campos et al., 2006).

However, despite the environmental risks when the cassava wastewater is improperly disposed in the environment, several authors consider its reused as thickener for the pharmaceutical industry (AntonioCisneiros \& Elizalde-Gonzalez, 2010) and as nematicide (Nasu et al., 2010) and bio-fertilizer for agricultural soils (Fioretto, 1987).

Silva et al. (2004), Barreto et al. (2014) and Magalhães et al., (2014) successfully used cassava wastewater as source of nutrients for sorghum and corn crops, which can be used for biofuel production, showing its nutrient content and benefits, reducing the inherent environmental risks of improperly disposed and the need for mineral fertilizers.

In this context, the objective of this work was to evaluate morphological and production components and oil yield of sunflower, hybrid Helio-250, fertilized with cassava wastewater.

\section{MATERIAL AND METHODS}

The experiment was conducted at the Experimental Station of the Instituto Agronômico de Pernambuco (Agricultural Research Institute of Pernambuco), Vitória de Santo Antão, State of Pernambuco (PE), Brazil ( $8^{\circ} 62$ S, $35^{\circ} 172 \mathrm{~W}$ and $146 \mathrm{~m}$ of altitude), from October 2012 to January 2013. According to the classification of Köppen, the climate of the region is As', tropical hot and humid, with two well defined seasons, rainy (January to June) and dry (July to December).

The soil of the experimental area was classified as Oxisol. Four simple soil samples (layer of 0.00-0.40 m) were collected in each block using an auger. Subsequently, the samples were air-dried, disaggregated, sieved in a 2-mm mesh sieve and homogenized, forming two composite samples for each block.

The physical and chemical characteristics of the soil of the experimental area (Table 1) were assessed in the Laboratory of Soil Chemistry and Fertility and in the Laboratory of Soil Mechanics and Waste Utilization of the Universidade Federal Rural de Pernambuco (Federal Rural University of Pernambuco - UFRPE), following the methods described by Embrapa (1997).

A randomized block experimental design was used, with six cassava wastewater rates $(0,8.5,17.0,34.0,68.0$ and 136 $\left.\mathrm{m}^{3} \mathrm{ha}^{-1}\right)$ and four replications. Each block consisted of six experimental plots with four 6-m plant rows spaced $1.0 \mathrm{~m}$ apart with $0.20 \mathrm{~m}$ between plants, totaling 120 plants per plot. The evaluation area of the plot $\left(10.4 \mathrm{~m}^{2}\right)$ consisted of the 52 central plants of the two central rows, considering the two external rows and the 2 plants of each end of the rows as border.

According to the sunflower crop requirement and the soil potassium content, the potassium rate recommended was $30 \mathrm{~kg} \mathrm{ha}^{-1}$ (Ribeiro et al., 1999), which represented $8 \mathrm{~m}^{3}$

Table 1: Physical and chemical characteristics of the soil (layer $0.0-0.40 \mathrm{~m}$ ) of the experimental area

\begin{tabular}{lc}
\hline Parameters & Values \\
\hline Sand $\left(\mathrm{g} \mathrm{kg}^{-1}\right)$ & 597 \\
Silt $\left(\mathrm{g} \mathrm{kg}^{-1}\right)$ & 113 \\
Clay $\left(\mathrm{g} \mathrm{kg}^{-1}\right)$ & 290 \\
Textural class & sandy loam \\
pH in water & 6.60 \\
Organic carbon $\left(\mathrm{g} \mathrm{kg}^{-1}\right)$ & 28.0 \\
Phosphorus $\left(\mathrm{mg} \mathrm{dm}^{-3}\right)$ & 7.70 \\
Potassium $\left(\mathrm{cmol}_{\mathrm{c} .} \mathrm{dm}^{-3}\right)$ & 0.45 \\
Sodium $\left(\mathrm{cmol}_{\mathrm{c}} \mathrm{dm}^{-3}\right)$ & 0.27 \\
Calcium $\left(\mathrm{cmol}_{\mathrm{c} .} \mathrm{dm}^{-3}\right)$ & 2.70 \\
Magnesium $\left(\mathrm{cmol}_{\mathrm{c} .} \mathrm{dm}^{-3}\right)$ & 2.80 \\
Aluminum $\left(\mathrm{cmol}_{\mathrm{c}} \mathrm{dm}^{-3}\right)$ & 0.00 \\
Hydrogen + Aluminum $\left(\mathrm{cmol}_{\mathrm{c} .} \mathrm{dm}^{-3}\right)$ & 2.93 \\
\hline
\end{tabular}


ha $^{-1}$ of cassava wastewater, considering the potassium content in this residue. The other rates used were based on multiples of the recommended rate (2-, 4-, 8- and 16-fold the recommended rate).

The cassava wastewater used was from the pressing process of cassava roots for table flour production of a flour industry, located in Pombos, PE, Brazil. The physical and chemical composition of the wastewater (Table 2) was assessed in the Laboratory of Environmental Engineering and Quality of the UFRPE, according to the methodology described by APHA (1995).

The soil preparation consisted of plowing, harrowing and furrowing, with row spacing of $1.0 \mathrm{~m}$ and depth of 0.3 $\mathrm{m}$. A drip irrigation system was used, with 16-mm flexible dripline, emitters spaced $0.2 \mathrm{~m}$ apart and flow of $1.0 \mathrm{~L} \mathrm{~h}^{-1}$. The irrigation water depth $(325 \mathrm{~mm})$, applied in each irrigation during the crop cycle (90 days) was determined based on the crop evapotranspiration, calculated with climatologic data from a weather station of the Centro de Previsão de Tempo e Estudos Climáticos (Center for Weather Forecasting and Climate Studies - CPTEC/INPE), in Vitória do Santo Antão PE.

Seeds of the sunflower hybrid Helio-250 were directly sown in the field, placing five seeds per hole. After emergency, the plants were thinned, leaving one plant per hole. The cultural practices consisted of manual weeding, phytosanitary control using natural pesticides and manual harvesting, since the area used was intended for organic production.

Mineral fertilizers and lime were not applied during the experiment, in order to evaluate only the effect of the cassava wastewater on the crop. The cassava wastewater rates were applied in a single application, at 15 days before sowing the sunflower seeds.

The plants were harvested for evaluation at 90 days after sowing, when the sunflower capitula were already facing downwards. The variables evaluated were shoot fresh (SFW) and dry (SDW) weight $\left(\mathrm{kg} \mathrm{ha}^{-1}\right)$, capitulum

Table 2: Physical and chemical characteristics of the cassava wastewater

\begin{tabular}{lc}
\hline Parameters & Content \\
\hline Chemical oxygen demand $\left(\mathrm{mg} \mathrm{L}^{-1}\right)$ & 66,617 \\
Electric conductivity $\left.(\mathrm{dS} \mathrm{m})^{-1}\right)$ & 7.27 \\
$\mathrm{pH}$ & 6.60 \\
Nitrogen $\left(\mathrm{mg} \mathrm{L}^{-1}\right)$ & 3,064 \\
Phosphorus $\left(\mathrm{mg} \mathrm{L}^{-1}\right)$ & 312 \\
Potassium $\left(\mathrm{mg} \mathrm{L}^{-1}\right)$ & 3,200 \\
Calcium $\left(\mathrm{mg} \mathrm{L}^{-1}\right)$ & 241.90 \\
Magnesium $\left(\mathrm{mg} \mathrm{L}^{-1}\right)$ & $1,588.20$ \\
Sodium $\left(\mathrm{mg} \mathrm{L}^{-1}\right)$ & 390 \\
Sulfate $\left(\mathrm{mg} \mathrm{L}^{-1}\right)$ & 2,205 \\
Chlorides $\left(\mathrm{mg} \mathrm{L}^{-1}\right)$ & 795 \\
\hline
\end{tabular}

fresh $(\mathrm{CFW})$ and dry (CDW) weight $\left(\mathrm{kg} \mathrm{ha}^{-1}\right)$, capitulum diameter $(\mathrm{CD})(\mathrm{cm})$, seed yield corrected to $11 \%$ of moisture $\left(\mathrm{kg} \mathrm{ha}^{-1}\right.$ ), seed oil content (\%) by the Soxhlet method as described by Bezerra Neto \& Barreto (2011), and oil yield $\left(\mathrm{kg} \mathrm{ha}^{-1}\right.$ ) obtained by the product of the seed oil content $\left(\mathrm{kg} \mathrm{ha}^{-1}\right)$ and seed yield $\left(\mathrm{kg} \mathrm{ha}^{-1}\right)$.

Data were subjected to analysis of variance and regression with significance levels of $5 \%$.

\section{RESULTS AND DISCUSSION}

The variables shoot fresh (SFW) and dry (SDW) weight, and capitulum fresh (CFW) dry (CDW) weight of the sunflower plants (Figures 1 A, B, C and D) showed a positive linear response to increasing cassava wastewater rates (CWR).

The minimum $\left(20,967 \mathrm{~kg} \mathrm{ha}^{-1}, \mathrm{CWR}\right.$ of 0$)$ and maximum $\left(65,881 \mathrm{~kg} \mathrm{ha}^{-1}\right.$, CWR of $\left.136 \mathrm{~m}^{3} \mathrm{ha}^{-1}\right) \mathrm{SFW}$ found by the regression equations (Figure $1 \mathrm{~A}$ ) represented an increase of $214 \%$. The CWR of 0 resulted in the minimum SDW (4.287 $\mathrm{kg} \mathrm{ha}^{-1}$ ) and the CWR of $136 \mathrm{~m}^{3} \mathrm{ha}^{-1}$ resulted in the highest SDW, representing an increase of $219 \%$ (Figure 1B).

Increases in shoot fresh and dry weight of plants of several crops have been related to the use of organic fertilizers, such as the cassava wastewater. Barreto et al. (2014) evaluated the initial growth of maize in a greenhouse on soils (sandy loam and clay loam) fertilized with raw untreated cassava wastewater rates $(0,11.2,22.4$ and 44.8 $\mathrm{m}^{3} \mathrm{ha}^{-1}$ ) and found significant increases in SFW and SDW. Magalhães et al. (2014) evaluated maize grown on soil fertilized with CWR $\left(0,12.6,25.2,50.4\right.$ and $\left.75.6 \mathrm{~m}^{3} \mathrm{ha}^{-1}\right)$ during 60 days and found higher leaf and stem fresh and dry weights in treatments with CWR of $63 \mathrm{~m}^{3} \mathrm{ha}^{-1}$, which decreased with higher rates, denoting a probably nutritional imbalance in the plants depending on the chemical composition of the residue.

According to Fageria (2001), excess ions in the soil solution, such as potassium, which is an abundant nutrient in the cassava wastewater, can affect the absorption of other essential nutrients to plants, such as calcium, magnesium, zinc and manganese, due to the antagonism between potassium and these elements.

The SFW of sunflower plants grown under the highest CWR was lower than the that found by Oliveira et al. (2010) $\left(83,900 \mathrm{~kg} \mathrm{ha}^{-1}\right)$, in sunflower grown in soil fertilized with mineral fertilizers, with plant density of 60,000 plants ha-1 $^{-1}$.

The lower the shoot fresh and dry fractions of sunflower plants, the higher the capitulum fraction (Oliveira et al., 2010). Therefore, plants with low shoot fresh and dry weight may have higher seed production and, consequently, higher oil yield and nutritional value, which is an important characteristic when the plants are used for silage (Joner et al., 2011). 


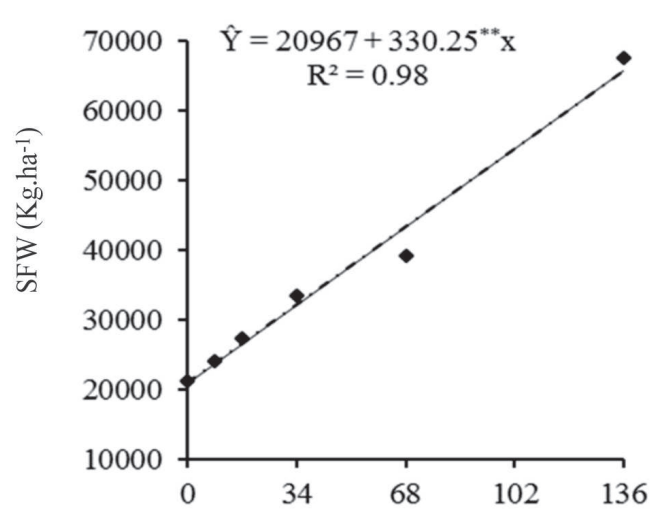

A Cassava wastewater rates $\mathrm{m}^{3} \mathrm{ha}^{-1}$

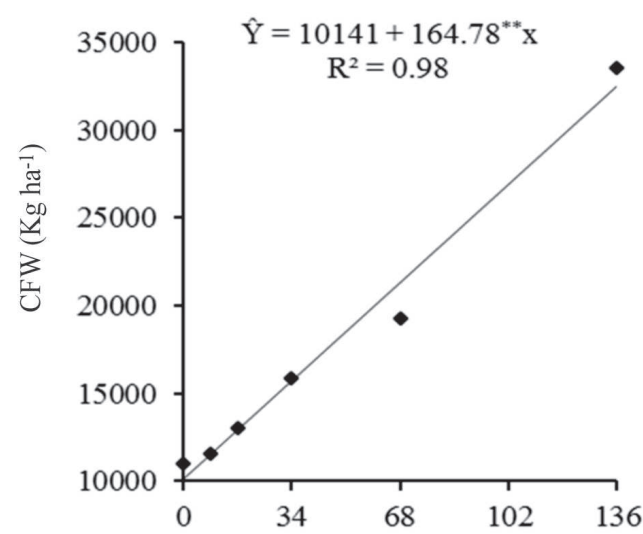

C Cassava wastewater rates $\mathrm{m}^{3} \mathrm{ha}^{-1}$

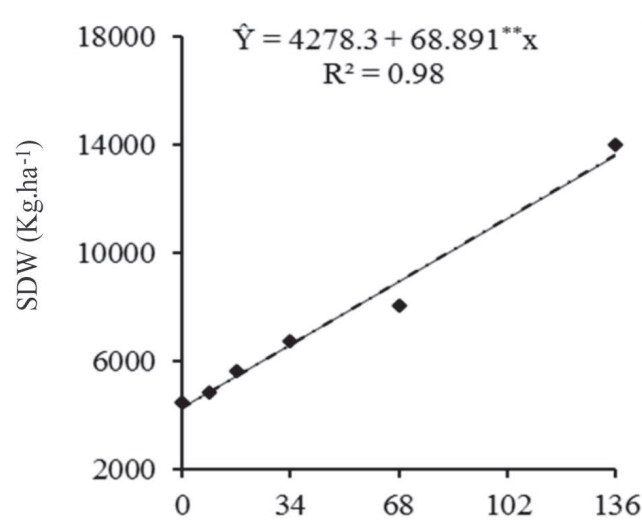

B Cassava wastewater rates $\mathrm{m}^{3} \mathrm{ha}^{-1}$

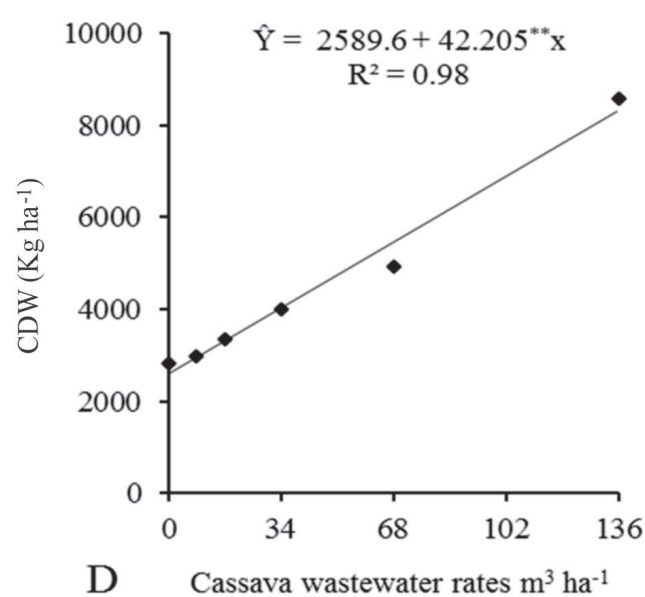

Figure 1: Shoot fresh (SFW) (A) and dry weight (SDW) (B) and capitulum fresh (CFW) (C) and dry (CDW) (D) weight of sunflower (Helianthus annuus) grown under different cassava wastewater rates.

According to the regression equations, the CFW and CDW presented positive linear responses to the CWR (Figures $1 \mathrm{C}$ and $\mathrm{D})$. The $\mathrm{CFW}$ and $\mathrm{CDW}$ at CWR of 0 was 10,141 and 2,589 $\mathrm{kg} \mathrm{ha}^{-1}$, representing 219.5 and $56.2 \mathrm{~g}$ plant $^{-1}$, respectively. On the other hand, the CWR of 136 $\mathrm{m}^{3} \mathrm{ha}^{-1}$ resulted in a CFW of 32,55.1 kg ha-1 and CDW of $8,328.9 \mathrm{~kg} \mathrm{ha}^{-1}$.

The CDW of sunflower plants grown on soils fertilized with cassava wastewater were higher than those found by Zobiole et al. (2010) with mineral fertilization $(3,882.5 \mathrm{~kg}$ $\left.\mathrm{ha}^{-1}\right)$. Joner et al. (2011) evaluated the production and the fresh and dry fractions of seeds, leaves, stems and capitula of two sunflower hybrids (Helio-251 and Helio-360) for silage production and found CDW of 1,315.54 (Helio-251) and $2,180.89 \mathrm{~kg} \mathrm{ha}^{-1}$ (Helio-360) and CFW of 6,473.65 (Helio-251) and 11,648.04 $\mathrm{kg} \mathrm{ha}^{-1}$ (Helio-360). These results show that the cassava wastewater was an efficient source of nutrients for the sunflower crop in the present work.

The capitulum diameter (CD) of the sunflower plants significantly increased with increasing CWR; the CD increased from $12 \mathrm{~cm}\left(\mathrm{CWR}\right.$ of $\left.0 \mathrm{~m}^{3} \mathrm{ha}^{-1}\right)$ to $18.4 \mathrm{~cm}(\mathrm{CWR}$ of $136 \mathrm{~m}^{3} \mathrm{ha}^{-1}$ ) (Figure 2). According to Joner et al. (2011), the capitulum diameter is important due to the amount of seeds produced, which determines the oil yield.

Bruginski \& Pissaia (2002) assessed the effect of topdressing with different nitrogen rates $(0,25,50,75,100$ and $125 \mathrm{~kg} \mathrm{ha}^{-1}$ ) on sunflower (Hybrid M-734) crops, and found CD of $16.0\left(0 \mathrm{~kg} \mathrm{ha}^{-1}\right)$ to $18.4 \mathrm{~cm}\left(50 \mathrm{~kg} \mathrm{ha}^{-1}\right)$ at the

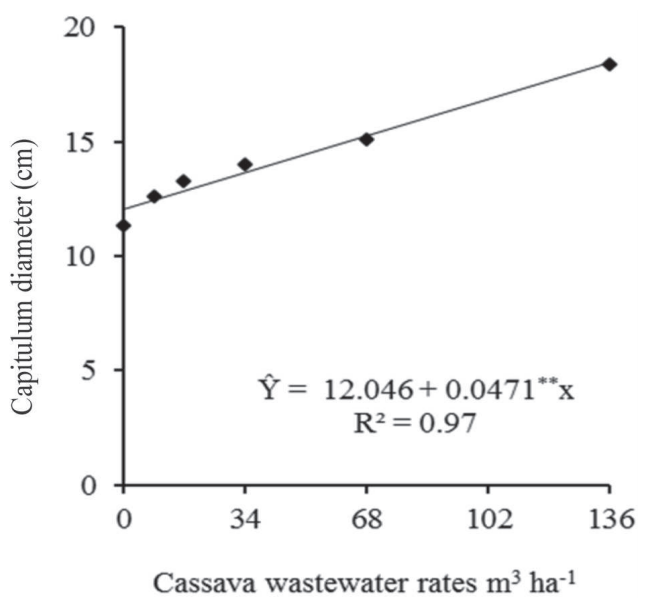

Figure 2: Capitulum diameter of sunflower (Helianthus annuus) grown under different cassava wastewater rates. 
crop R7 stage, with no negative effect by increasing nitrogen rates.

The $\mathrm{CD}$ found in the present work were also higher than those found by Thomaz et al. (2012) in different sunflower cultivars, including Helio-250, in crops intended for biofuel production. Therefore, these results denoted that the nutritional contribution of the CWR of $136 \mathrm{~m}^{3}$ ha ${ }^{1}$ had a positive effect on this morphological variable.

The sunflower seed yield (SSY) (Figure 3A) and oil yield (OY) (Figure 3B) were positively affected by increasing CWR, reaching 4,562.52 $\mathrm{kg} \mathrm{ha}^{-1}$ (SSY) and 1,965.19 $\mathrm{kg} \mathrm{ha}^{-1}$ (OY). On the other hand, results of the seed oil content (SOC) fitted a quadratic model, reaching a maximum SOC of $56 \%$ (Figure 3C) with CWR of $25 \mathrm{~m}^{3} \mathrm{ha}^{1}$.

Aquino et al. (2013) evaluated agronomic and nutritional characteristics of sunflower cultivars grown under field conditions, using mineral fertilizers, and found SSY of 3,950 kg ha-1 (Helio-250) and 4,631 kg ha-1 (Helio251). They attributed these high yields to the favorable temperature and water availability during the crop cycle. Thomaz et al. (2012) evaluated the SSY and SOC of sunflower plants sowed at ten different times and grown under field conditions and found a SSY of $1,329 \mathrm{~kg} \mathrm{ha}^{-1}$ for

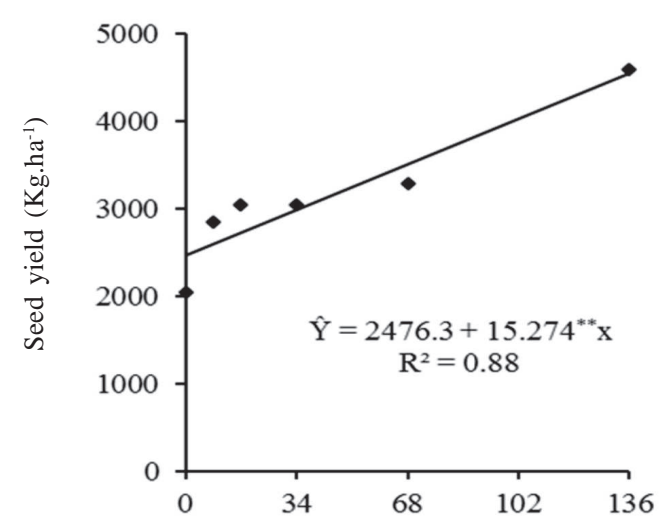

A Cassava wastewater rates $\mathrm{m}^{3} \mathrm{ha}^{-1}$

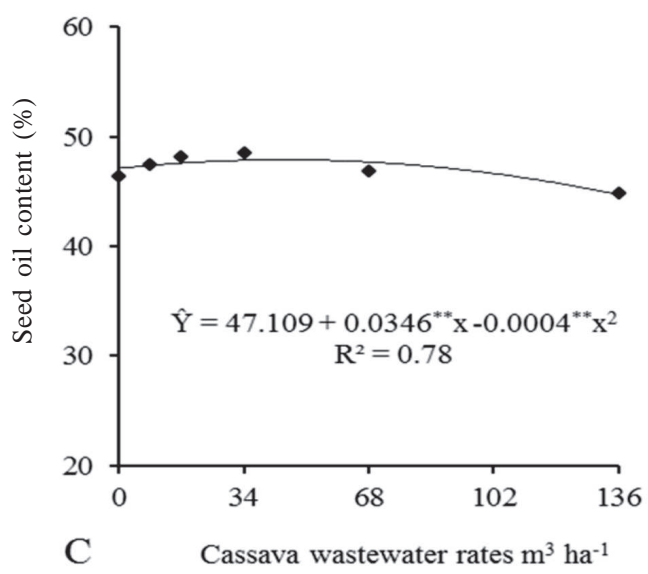

the cultivar Helio-250, which was lower than the average yields found for the hybrids M-734 (1,820 $\left.\mathrm{kg} \mathrm{ha}^{-1}\right)$, Aguará-4 (1,805 $\left.\mathrm{kg} \mathrm{ha}^{-1}\right)$ and Catissol (1,368 $\left.\mathrm{kg} \mathrm{ha}^{-1}\right)$. However, the hybrid Helio-250 had higher SOC in all sowing times (51.8 to $37.4 \%$ ), which were lower in later planting times due to the lower solar radiation.

Variations in the sunflower SOC are related to genetic characteristics, edaphoclimatic conditions and cultural practices, especially irrigation and fertilization managements. According to Biscaro et al. (2008), nitrogen significantly affects the metabolism and nutrition of sunflower crops; the deficiency of this nutrient limits production and its excess decreases the seed oil content, despite increasing protein content. The cassava wastewater used in the present work had high nitrogen concentration (Table 2), which probably resulted in the decreased of SOC from the CWR of $25 \mathrm{~m}^{3} \mathrm{ha}^{-1}$.

Uchôa et al. (2011) evaluated the agronomic responses of three sunflower cultivars (Agrobel-967, Agrobel-960 and Embrapa-122/V2000) subjected to topdressing with different potassium rates $\left(0,30,60,90\right.$ and $120 \mathrm{~kg} \mathrm{ha}^{-1}$ of $\mathrm{K}_{2} \mathrm{O}$ ) and found maximum SOC of $52.5 \%$ and $\mathrm{OY}$ of $1,079.3$ $\mathrm{kg} \mathrm{ha}^{-1}$ with potassium rates of 84.62 and $85.62 \mathrm{~kg} \mathrm{ha}^{-1}$,

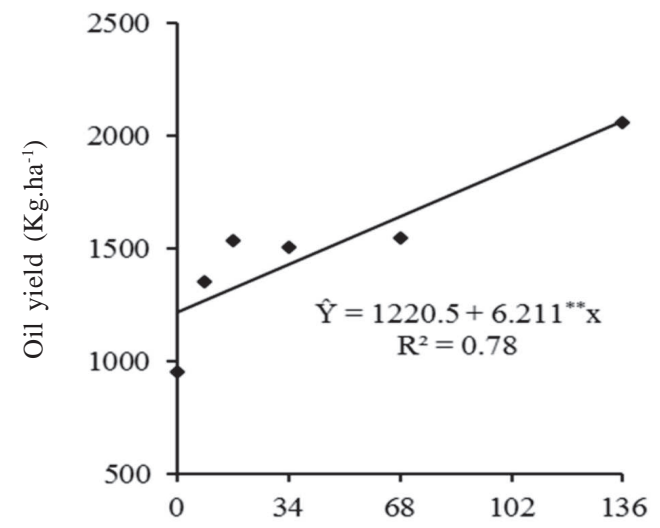

B Cassava wastewater rates $\mathrm{m}^{3} \mathrm{ha}^{-1}$

Figure 3: Seed yield (A), oil yield (B) and seed oil content (C) of sunflower (Helianthus annuus) grown under different cassava wastewater rates. 
respectively. According to these authors, the addition of nitrogen and potassium favored the seed production and SOC of the sunflower crop, indicating the importance of an adequate $\mathrm{P}$ and $\mathrm{N}$ rate for soil fertilization before planting and the correct fractionation of the topdressing.

The comparison of the results found in the present work with others from studies developed under field conditions and with mineral fertilization denoted the cassava wastewater nutritional contribution to the development of sunflower, which adequately met the requirements of the sunflower cultivar Helio-250. Moreover, the application of cassava wastewater in the soil had no negative effects on the morphological and production variables evaluated.

\section{CONCLUSIONS}

Cassava wastewater is an adequate source of nutrients for the sunflower hybrid Helio-250.

The use cassava wastewater as soil fertilizer improved the morphological and production variables evaluated, except the seed oil content, which decreased with application of cassava wastewater rates above $25 \mathrm{~m}^{3} \mathrm{ha}^{-1}$.

\section{REFERENCES}

Antonio-Cisneros CM \& Elizalde-Gonzalez MP (2010) Characterization of Manihot residues and preparation of activated carbon. Biomass and Bioenergy, 34:389-395.

APHA - American Public Health Association / AWWA - American Water Works Association / WPCF - Washington Press Club Foundation (1995) Standard methods for the examination of water and wastewater. $17^{\text {th }}$ ed. Washington, American Public Health Association. 2198p.

Aquino LA, Silva FDB \& Berger PG (2013) Características agronômicas e estado nutricional de cultivares de girassol irrigado. Revista Brasileira de Engenharia Agrícola e Ambiental, 17:551557.

Barreto MTL, Magalhães AG, Rolim MM, Pedrosa EMR, Duarte AS \& Tavares UE (2014) Desenvolvimento e acúmulo de macronutrientes em plantas de milho biofertilizadas com manipueira. Revista Brasileira de Engenharia Agrícola e Ambiental, 18:487-494.

Bezerra Neto E \& Barreto LP (2011) Análises químicas e bioquímicas em plantas. $3^{\mathrm{a}}$ ed. Recife, UFRPE. $148 \mathrm{p}$.

Biscaro GA, Machado J R, Tosta MS, Mendonça V, Soratto RP \& Carvalho LA (2008) Adubação nitrogenada em cobertura no girassol irrigado nas condições de Cassilândia-MS. Ciência e Agrotecnologia, 32:1366-1373.

Bruginski DH \& Pissaia A (2002) Cobertura nitrogenada em girassol sob plantio direto na palha: II morfologia da planta e partição de massa seca. Scientia Agraria, 3:47-53.

Campos AT, Daga J, Rodrigues EE, Franzener G, Suguy MM \& Syperreck VIG (2006) Tratamento de águas residuárias de fecularia por meio de lagoas de estabilização. Engenharia Agrícola, 26:235-242.

Embrapa - Empresa Brasileira de Pesquisa Agropecuária (1997) Manual de análises químicas de solos, plantas e fertilizantes. Brasília, Embrapa. 370p.
Fageria NK (2001) Nutrient interactions in crop plants. Journal of Plant Nutrition, 24:1269-1290.

FAO - Food and Agriculture Organization of the United Nations (2015) FAOSTAT 2015. Acessado em 05 de dezembro de 2016. Disponível em: <http://www.fao.org/faostat/en/>.

Fioretto RA (1987) Manipueira na fertirrigação: efeito sobre a germinação e a produção de algodão (Gossypium hirsutm, L.) e milho (Zea mays, L.). Semina, 8:17-20.

Grigatti M, Girolamo GD, Chincarini R, Ciavatta C \& Barbanti L (2011) Potential nitrogen mineralization, plant utilization efficiency and soil $\mathrm{CO}_{2}$ emissions following the addition of anaerobic digested slurries. Biomass and Bioenergy, 35:46194629.

Joner G, Metz PAM, Arboitte MZ, Pizzuti LAD, Brondani IL \& Restle J (2011) Aspectos agronômicos e produtivos dos híbridos do girassol (Helianthus annus L.) Helio 251 e Helio 360. Ciência Animal Brasileira, 12:266-273.

Magalhães AG, Rolim MM, Duarte AS, Bezerra Neto E, Tabosa JN \& Pedrosa EMR (2014) Desenvolvimento inicial do milho submetido à adubação com manipueira. Revista Brasileira de Engenharia Agrícola e Ambiental, 18:675-681.

Moraes MT, Silva VR \& Arnuti F (2012) Resíduos líquidos de efluentes de agroindústria de carnes na produtividade de girassol. Enciclopédia Biosfera, 8:843-853.

Nasu EGC, Pires E, Formentini HM \& Furlanetto C (2010) Efeito de manipueira sobre Meloidogyne incognita em ensaios in vitro e em tomateiros em casa de vegetação. Tropical Plant Pathology, $35: 32-36$.

Oliveira LB, Pires AJV, Viana AES, Matsumoto SN, Carvalho GGPL \& Ribeiro SO (2010) Produtividade, composição química e características agronômicas de diferentes forrageiras. Revista Brasileira de Zootecnia, 39:2604-2610.

Ribeiro AC, Guimarães PTG \& Alvarez VH (1999) Recomendações para o uso de corretivos e fertilizantes em Minas Gerais. 5 Aproximação. Viçosa, Comissão de Fertilidade do Solo do Estado de Minas Gerais. 359p.

Silva FF, Freitas PSL, Bertonha A, Muniz AS \& Rezende R (2004) Impacto da aplicação de efluente maturado de fecularia de mandioca em solo e na cultura do sorgo. Acta Scientiarum. Agronomy, 26:421-427.

Thomaz GL, Zagonel J, Colasante LO \& Nogueira RR (2012) Produção do girassol e teor de óleo nos aquênios em função da temperatura do ar, precipitação pluvial e radiação solar. Ciência Rural, 42:1380-1385.

Uchôa SCP, Ivanoff MEA, Alves JMA, Sedyama AT \& Martins SA (2011) Adubação de potássio em cobertura nos componentes de produção em cultivares de girassol. Revista Ciência Agronômica, 41:8-15

Virmond E (2011) Utilização de resíduos agroindustriais como fonte alternativa de energia. Tese de Doutorado. Universidade Federal de Santa Catarina, Florianópolis. 264p.

Zobiole LHS, Castro C, Oliveira FA, Oliveira Júnior A \& Moreira A (2010) Curva de crescimento, estado nutricional, teor de óleo e produtividade do girassol híbrido BRS 191 cultivado no Estado do Paraná. Revista Brasileira de Oleaginosas e Fibrosas, 14:5562 .

Rev. Ceres, Viçosa, v. 64, n.1, p. 077-082, jan/fev, 2017 